\title{
Bell Pepper (Capsicum annuum L.) Fruits are Susceptible to Chilling Injury at the Breaker Stage of Ripeness
}

\author{
Chae Shin Lim, Seong Mo Kang, and Jeoung Lai Cho ${ }^{1}$ \\ Department of Horticulture, Division of Applied Life Science, Gyeongsang \\ National University, 900 Gazwa-dong, Jinju 660-701, Republic of Korea \\ (South)
}

Kenneth C. Gross

Produce Quality and Safety Laboratory, USDA/ARS, Beltsville Agricultural Research Center, Building 002, 10300 Baltimore Avenue, Beltsville, MD 20705-2350

\section{Allan B. Woolf \\ The Horticulture and Food Research Institute of New Zealand Limited, Mt. Albert Research Centre, Private Bag 92169, Mt. Albert, New Zealand}

Additional index words. chroma, electrolyte leakage, fruit ripeness, hue, surface pitting, total color difference

\begin{abstract}
To study ripening-related chilling injury (CI) of bell pepper (Capsicum annuum L.), fruit at mature green, breaker, and red-ripe stages were stored at $1,5,7$, and $10{ }^{\circ} \mathrm{C}$ for 4 weeks. Surface pitting was evaluated after storage at $1^{\circ} \mathrm{C}$ for 2 weeks followed by a 2-day exposure to room temperature $\left(20^{\circ} \mathrm{C}\right)$. Exposing fruit to $1^{\circ} \mathrm{C}$ enhanced water loss, respiration, ethylene production, and electrolyte leakage, but slowed color change. Weight loss, respiration, ethylene production, electrolyte leakage, and color change increased more in breaker than in mature green and red-ripe fruit. No pitting symptom was observed at temperatures of 5 to $10{ }^{\circ} \mathrm{C}$. After storing peppers at $1{ }^{\circ} \mathrm{C}$ for 2 weeks, breaker stage fruit exhibited chilling symptoms of severe surface pitting with more sheet pitting and deeper peel depression. Mature green fruit showed only moderate pitting. However, red-ripe peppers showed no injury and cells showed a normal appearance after low-temperature storage $\left(1^{\circ} \mathrm{C}\right)$. These results show that bell peppers tended to be more susceptible to chilling temperature while at the breaker stage and that the increase in visible $\mathrm{CI}$ is correlated with increased water loss, respiration, ethylene production, electrolyte leakage, and color change during storage.
\end{abstract}

Sweet cultivars of Capsicum annuum L. are widely cultivated throughout the world because of their nutritional value, flavor, and color. However, bell peppers are susceptible to chilling injury (CI) below $7^{\circ} \mathrm{C}$ (Paull, 1990) depending on cultivar and maturity (Meir et al., 1995). The primary CI symptoms are surface pitting, calyx discoloration, and shriveling resulting from moisture loss (Hardenburg et al., 1986; Lin et al., 1993). Physiological manifestations of CI such as increased ethylene production, respiration, and electrolyte leakage (EL) usually precede or occur concomitantly with appearance of visible symptoms (Purvis, 2002).

Peppers have been classified as nonclimacteric fruit (Lurie et al., 1986). However,

\footnotetext{
Received for publication 14 Mar. 2007. Accepted for publication 1 July 2007.

We gratefully acknowledge the financial support provided by the BK 21 project, Inst. of Agri. \& Life. Sci. GNU, Rural Development Administration, and Agricultural R\&D Promotion Center in Korea. ${ }^{1}$ To whom reprint requests should be addressed; e-mail jlcho@nongae.gsnu.ac.kr and limsabin@ daum.net
}

of chilling symptoms at different ripeness stages. Thus, the objective of this study was to determine the effect of ripeness stage on CI development and to find a relationship between symptoms of CI and peel pitting in bell peppers during cold storage.

\section{Materials and Methods}

Plant materials and storage conditions. Bell pepper fruits (cv. Plenty) were harvested from a commercial greenhouse in Daegock, Gyeongnam Province, South Korea. Fruit at three ripeness stages were selected based on uniform fruit size $(\approx 180 \mathrm{~g}$ per fruit in weight) and three maturities on skin color: GS, mature green (full-sized fruit just before the onset of ripening); BS, breaker (incipient red color formation); and RS, red-ripe (fruit completely red in color). Fruit were washed with tap water and then air-dried at room temperature. To provide similar humidity conditions (relative humidity 90\%) around fruits, regardless of storage temperatures, five fruits $(\approx 900 \mathrm{~g})$ that had been randomly selected were packed into sealed, nonperforated, low-density polyethylene bag $(52-\mu \mathrm{m}$ thick, $24.5 \times 35.5 \mathrm{~cm}$ in size, $\mathrm{O}_{2}$ permeability $\left.35 \mathrm{~mL} \cdot \mathrm{m}^{-2} \cdot \mathrm{h}^{-1} / \mathrm{atm}\right)$ before storage. To determine the effect of ripeness stage on inpackage atmosphere, weight loss, respiration, ethylene production, EL, and color change, fruit were stored at $1,5,7$, and $10{ }^{\circ} \mathrm{C}$ for 4 weeks. The bags were opened at 7-d intervals for each measurement and then, after measurement, all fruits were immediately returned to their original storage conditions until the next measurement. A second experiment was conducted to evaluate the effect of ripeness stage on development of surface pitting. Fruit were stored at $1{ }^{\circ} \mathrm{C}$ for $14 \mathrm{~d}$ followed by another $2 \mathrm{~d}$ at room temperature $\left(20{ }^{\circ} \mathrm{C}\right)$. Each experiment was carried out with three replications.

In-package atmosphere changes. The oxygen and carbon dioxide concentrations in the atmosphere inside the bags were determined the day after the bags were sealed and at 3-d intervals for 4 weeks. One milliliter of the headspace gas of the packages was withdrawn using a gas-tight glass syringe (Precision Sampling Corp., Baton Rouge, LA) through a silicone septum on the packages. Five bags were used for each replication. The oxygen and carbon dioxide concentrations were analyzed using a gas chromatograph (Hewlett Packard 6890, Wilmington, DE) with a thermoconductivity detector. The gases were separated in a packed column (Alltech CTR I, Deerfield, IL). Oven temperature was $100{ }^{\circ} \mathrm{C}$ and both inlet temperature and detector temperatures were $120^{\circ} \mathrm{C}$.

Weight loss. Each fruit was labeled and weighed individually at the beginning of the experiment $\left(\mathrm{W}_{\mathrm{t}=0}\right)$ and during storage $\left(\mathrm{W}_{\mathrm{t}=\mathrm{t}}\right)$. Any water that had condensed on the surface of fruit as a result of the temperature difference between storage containers and the laboratory was blot-dried before weighing. Thirteen fruits were used for each replication. Moisture loss was expressed as normalized 
percentage of weight loss (WL) by the following equation: WL $(\%)=\left[\left(\mathrm{W}_{\mathrm{t}}=0-\right.\right.$ $\left.\left.\mathrm{W}_{\mathrm{t}=\mathrm{t}}\right) / \mathrm{W}_{\mathrm{t}=0}\right] \times 100$.

Respiration and ethylene production. A single fruit weighed at the beginning of the experiment was put in a 1-L plastic jar (Straight-Side Jar; Nalgene, Rochester, NY) after equilibrating at $20^{\circ} \mathrm{C}$ for $1 \mathrm{~h}$. The jars were kept for another $1 \mathrm{~h}$ at $20^{\circ} \mathrm{C}$, and $1 \mathrm{~mL}$ of the headspace gas was then withdrawn using the gastight glass syringe. Carbon dioxide and ethylene were analyzed using the gas chromatograph equipped with a packed column (HP19001A-NO1, Wilmington, $\mathrm{DE})$. Both oven and inlet temperatures were $100{ }^{\circ} \mathrm{C}$ and the back inlet, front detector, and back detector temperatures were 375,250 , and $150{ }^{\circ} \mathrm{C}$, respectively. Fifteen fruits were used for each replication.

Electrolyte leakage. Electrolyte leakage was determined using a slightly modified method of Saltveit (2002). Fruit discs (5-mm diameter) were excised with a stainless steel cork borer. Fifteen fruits were used for each replication. Three tissue discs from each fruit were incubated in a $50-\mathrm{mL}$ plastic conical tube containing $20 \mathrm{~mL}$ of $0.2 \mathrm{M}$ mannitol solution. Conductivity of the solution was measured at the beginning of the incubation $\left(\mathrm{EL}_{0}\right)$ using a conductivity meter (F-54 BW; Horiba, Kyoto, Japan). The disc samples were agitated on a flatbed shaker at $60 \mathrm{rpm}$ for $24 \mathrm{~h}$ at $25^{\circ} \mathrm{C}$ and the conductivity of the

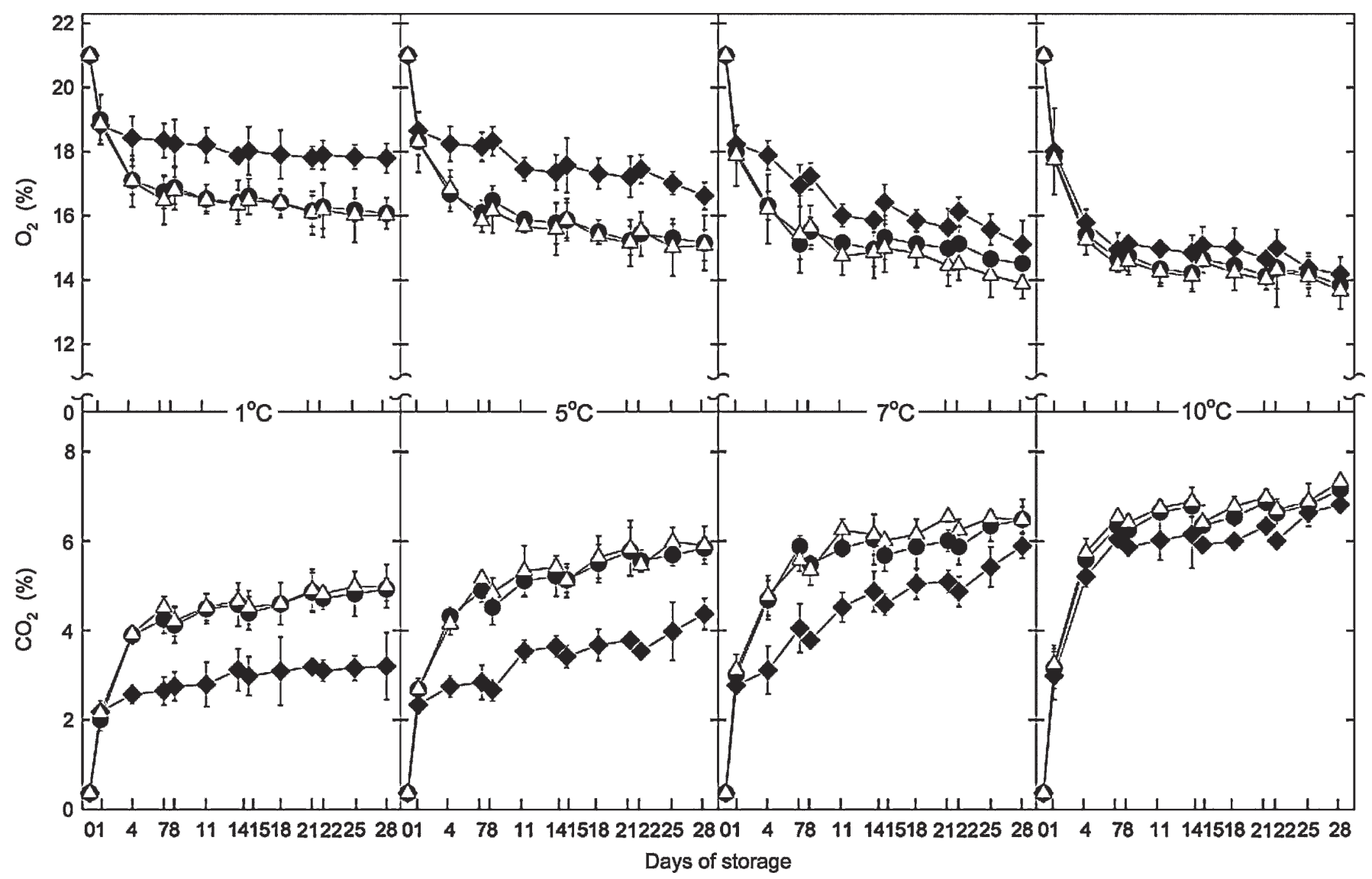

Fig. 1. Changes in oxygen and carbon dioxide levels (\%) inside the packages during storage of bell pepper fruit at $1,5,7$, or $10{ }^{\circ} \mathrm{C}$ as affected by stage of ripeness. The packages were open at seven-day intervals. Fruit were harvested at three different stages and stored for 4 weeks. Ripeness stages: GS, mature green (full size fruit just before the onset of ripening); BS, breaker (incipient red color formation); RS, red-ripe (fruit completely red in color). Vertical bars indicate SE of the mean. Where bars are not visible, SE does not exceed the size of the symbol.

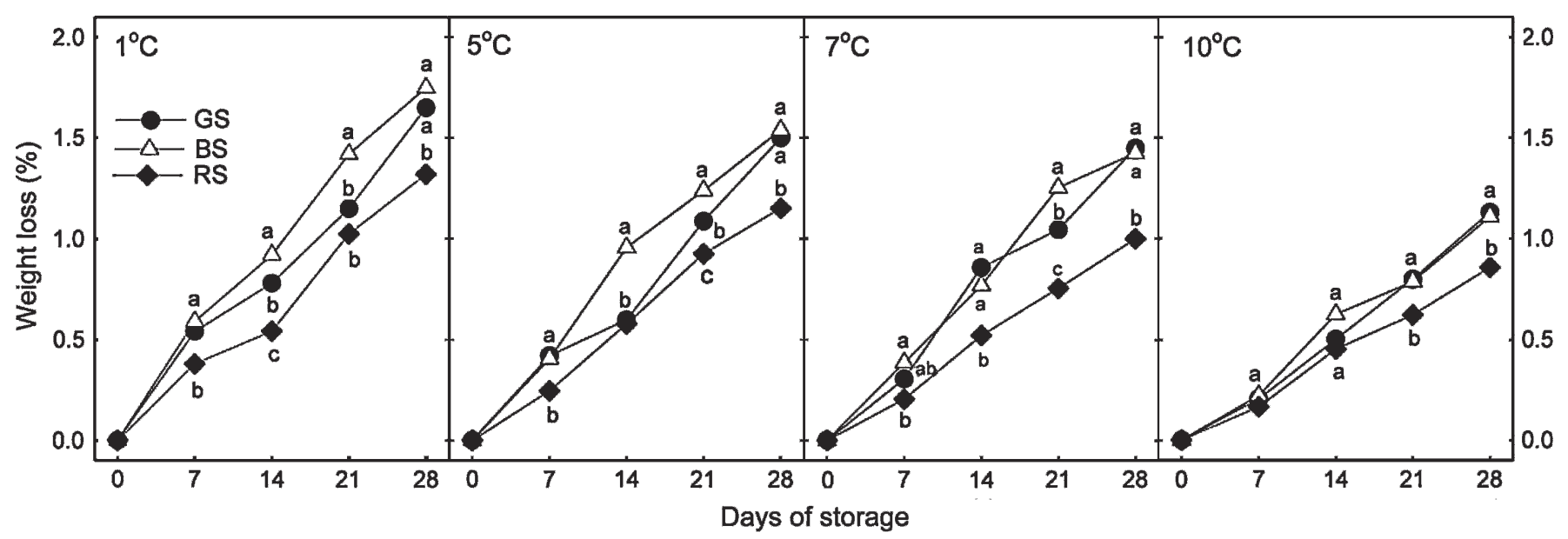

Fig. 2. Changes in weight loss of bell pepper fruit at $1,5,7$, or $10^{\circ} \mathrm{C}$ as affected by stage of ripeness. Fruit were harvested at three different stages and stored for 4 weeks. Ripeness stages: GS, mature green (full size fruit just before the onset of ripening); BS, breaker (incipient red color formation); RS, red-ripe (fruit completely red in color). Means within each date followed by different letters are significantly different at $P \leq 0.05$, LSD test. 
solution again measured $\left(\mathrm{EL}_{24}\right)$. To measure residual electrolytes remaining in the tissues, discs were frozen at $-20{ }^{\circ} \mathrm{C}$ for $24 \mathrm{~h}$ and then thawed before total conductivity of the solution was measured $\left(\mathrm{EL}_{\mathrm{t}}\right)$. EL was calculated using the following equation: EL $(\%)=$ $\left[\left(\mathrm{EL}_{24}-\mathrm{EL}_{0}\right) /\left(\mathrm{EL}_{\mathrm{t}}-\mathrm{EL}_{0}\right)\right] \times 100$.

Color change. Color changes of bell peppers were measured using a Minolta chroma meter (CR-200, light source D65; Osaka, Japan) calibrated with a white standard tile.

Fruit skin color at the end of storage was determined on the same shoulder portion of fruit that had been marked before storage. Thirty fruits were used for each replication. Color was recorded using the CIE-L*a*b* uniform color space (CIELAB), and numerical values of $a^{*}$ and $b^{*}$ were converted into hue angle $\left(\tan ^{-1} \mathrm{~b}^{*} / \mathrm{a}^{*}\right)$ and chroma $\left[\left(\mathrm{a}^{* 2}+\right.\right.$ $\left.b^{* 2}\right)^{1 / 2}$ ] according to Francis (1980). The hue is an angle in a color wheel of 360 with 0,90 , 180 , and 270 representing red-purple, yellow, bluish-green, and blue, respectively. The chroma is the intensity or purity of the hue. Together with $\mathrm{L}^{*}$, hue and chroma give an accurate description of the color of a sample. Total color difference was calculated using the following equation: $\Delta \mathrm{E}=\left[\Delta \mathrm{L}^{* 2}+\right.$ $\left.\Delta \mathrm{a}^{* 2}+\Delta \mathrm{b}^{* 2}\right]^{1 / 2}$

Surface pitting and scanning electron microscopy. Visible CI symptoms were assessed by scoring the degree of surface pitting after chilling at $1{ }^{\circ} \mathrm{C}$ for 2 weeks followed by a 2-d exposure to room temperature. Ten panelists were employed to perform the evaluation of surface pitting based on the percentage of surface area pitted. The surface pitting index (SPI) was based on a scale of 0 to 5 , in which 0 , no pitting; $1,5 \% ; 2,6 \%$ to

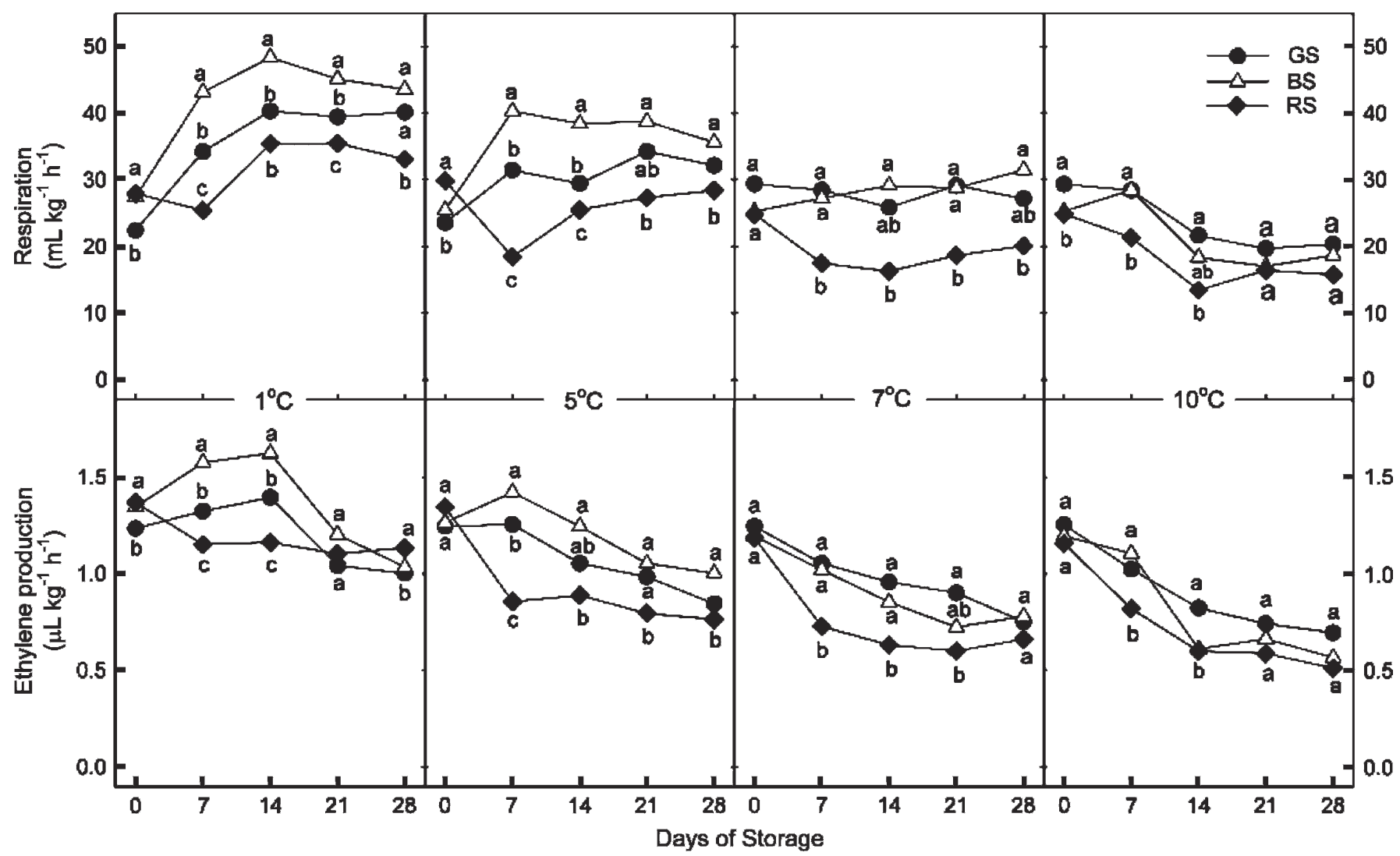

Fig. 3. Changes in respiration and ethylene production of bell pepper fruit at $1,5,7$, or $10^{\circ} \mathrm{C}$ as affected by stage of ripeness. Fruit were harvested at three different stages and stored for 4 weeks. Ripeness stages: GS, mature green (full size fruit just before the onset of ripening); BS, breaker (incipient red color formation); $\mathrm{RS}$, red-ripe (fruit completely red in color). Means within each date followed by different letters are significantly different at $P \leq 0.05$, LSD test.

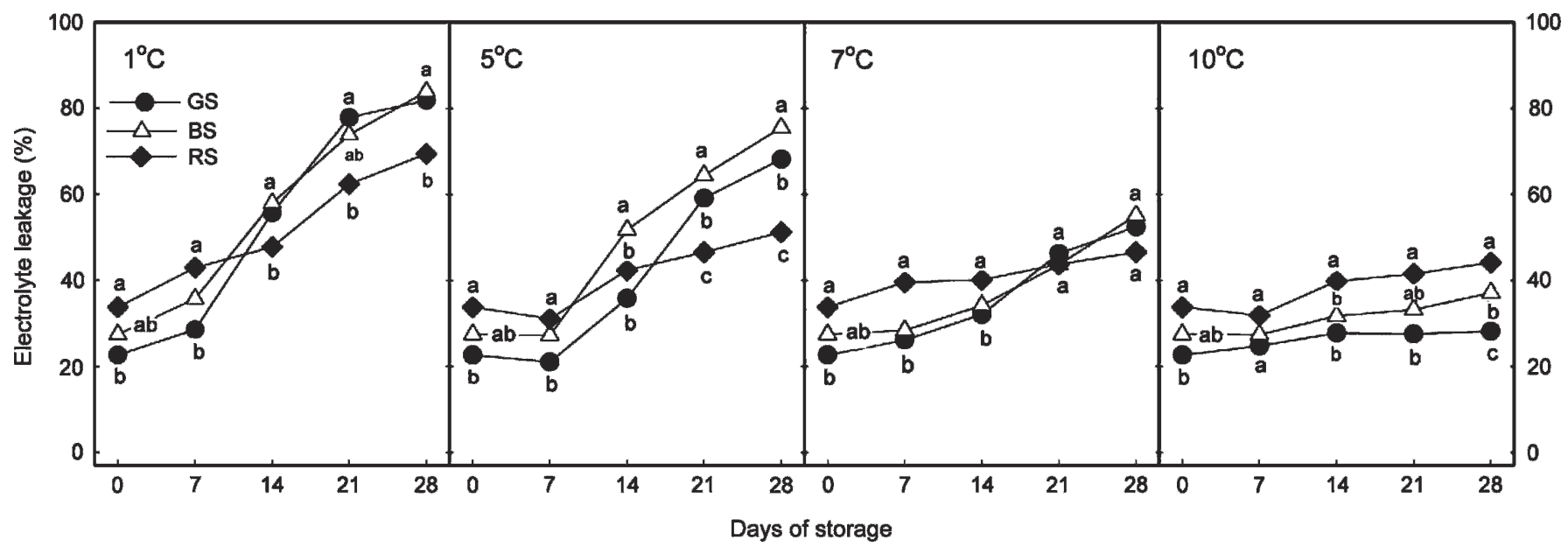

Fig. 4. Changes in electrolyte leakage of bell pepper fruit at $1,5,7$, or $10^{\circ} \mathrm{C}$ as affected by stage of ripeness. Fruit were harvested at three different stages and stored for 4 weeks. Ripeness stages: GS, mature green (full size fruit just before the onset of ripening); BS, breaker (incipient red color formation); RS, red-ripe (fruit completely red in color). Means within each date followed by different letters are significantly different at $P \leq 0.05$, LSD test. 


\begin{tabular}{|c|c|c|c|c|c|c|c|c|c|}
\hline \multirow[b]{4}{*}{ Storage temp. } & \multirow[b]{4}{*}{ Ripeness stage $^{z}$} & \multicolumn{8}{|c|}{ Color characteristics ${ }^{y}$} \\
\hline & & \multicolumn{2}{|c|}{$\mathrm{L}^{*}$} & \multicolumn{2}{|c|}{$\mathrm{h}^{\circ}$} & \multicolumn{2}{|c|}{$\mathrm{C}^{*}$} & \multicolumn{2}{|c|}{$\Delta \mathrm{E}$} \\
\hline & & \multicolumn{8}{|c|}{ Days of storage } \\
\hline & & 0 & 28 & 0 & 28 & 0 & 28 & 0 & 28 \\
\hline \multirow[t]{3}{*}{$1^{\circ} \mathrm{C}$} & BS & $36.2 \mathrm{a}$ & $34.3 \mathrm{a}$ & $113.4 \mathrm{~b}$ & $110.4 \mathrm{a}$ & $13.6 \mathrm{c}$ & $10.8 \mathrm{c}$ & 0.0 & $3.7 \mathrm{a}$ \\
\hline & RS & $36.5 \mathrm{a}$ & $34.6 \mathrm{a}$ & $28.3 \mathrm{c}$ & $29.0 \mathrm{c}$ & $34.7 \mathrm{a}$ & $35.4 \mathrm{a}$ & 0.0 & $2.4 \mathrm{a}$ \\
\hline & GS & $36.2 \mathrm{a}$ & $35.1 \mathrm{a}$ & $130.3 \mathrm{a}$ & $129.8 \mathrm{a}$ & $17.4 \mathrm{~b}$ & $16.9 \mathrm{~b}$ & 0.0 & $1.8 \mathrm{~b}$ \\
\hline $5^{\circ} \mathrm{C}$ & BS & $34.4 \mathrm{ab}$ & $32.1 \mathrm{~b}$ & $100.2 \mathrm{~b}$ & $88.5 \mathrm{~b}$ & $13.1 \mathrm{c}$ & $11.8 \mathrm{c}$ & 0.0 & $9.6 \mathrm{a}$ \\
\hline \multirow[t]{3}{*}{$7{ }^{\circ} \mathrm{C}$} & BS & $35.4 \mathrm{~b}$ & $38.8 \mathrm{~b}$ & $115.6 \mathrm{~b}$ & $75.6 \mathrm{~b}$ & $13.6 \mathrm{c}$ & $18.9 \mathrm{~b}$ & 0.0 & $16.5 \mathrm{a}$ \\
\hline & RS & $37.4 \mathrm{~b}$ & $36.6 \mathrm{~b}$ & $27.3 \mathrm{c}$ & $26.9 \mathrm{c}$ & $32.6 \mathrm{a}$ & $32.8 \mathrm{a}$ & 0.0 & $2.3 \mathrm{~b}$ \\
\hline & GS & $37.2 \mathrm{a}$ & $37.0 \mathrm{~b}$ & $128.5 \mathrm{a}$ & $123.2 \mathrm{a}$ & $18.8 \mathrm{~b}$ & $20.3 \mathrm{~b}$ & 0.0 & $3.3 \mathrm{~b}$ \\
\hline \multirow[t]{2}{*}{$10^{\circ} \mathrm{C}$} & BS & $34.8 \mathrm{~b}$ & $41.4 \mathrm{a}$ & $110.5 \mathrm{~b}$ & $56.3 \mathrm{~b}$ & $14.0 \mathrm{c}$ & $32.9 \mathrm{a}$ & 0.0 & $28.6 \mathrm{a}$ \\
\hline & RS & $34.5 \mathrm{~b}$ & $33.7 \mathrm{c}$ & $28.3 \mathrm{c}$ & $27.8 \mathrm{c}$ & $31.7 \mathrm{a}$ & $31.9 \mathrm{a}$ & 0.0 & $1.6 \mathrm{~b}$ \\
\hline \multicolumn{2}{|c|}{ Storage temperatures (A) } & $* *$ & $* * *$ & NS & $* * *$ & NS & $* * *$ & - & $* * *$ \\
\hline \multicolumn{2}{|c|}{ Ripeness stages (B) } & $* * *$ & $* * *$ & $* * *$ & $* * *$ & $* * *$ & $* * *$ & - & $* * *$ \\
\hline
\end{tabular}

${ }^{2}$ Ripeness stages: GS, mature green (full-sized fruit just before the onset of ripening); BS, breaker (incipient red color formation); RS, red-ripe (fruit completely red in color).

${ }^{y}$ Lightness $\left(\mathrm{L}^{*}\right)$ ranged from 0 (black) to 100 (white), chroma $\left(\mathrm{C}^{*}\right)=\left(\mathrm{a}^{2}+\mathrm{b}^{2}\right)^{1 / 2}$ with $0=$ least intense, hue angle $\left(\mathrm{h}^{\circ}\right)=\tan ^{-1}(\mathrm{~b} / \mathrm{a})$ with $0^{\circ}=$ red-purple, $90^{\circ}=$ yellow, $180^{\circ}=$ bluish-green, and $270^{\circ}=$ blue in the CIELAB color space, and total color difference $(\Delta \mathrm{E})=\left[\left(\Delta \mathrm{L}^{*}\right)^{2}+\left(\Delta \mathrm{a}^{*}\right)^{2}+\left(\Delta \mathrm{b}^{*}\right)^{2}\right]^{1 / 2}$.

${ }^{\mathrm{x}}$ The same letters in the column for each temperature are not significantly different at $0.05 \%$ by least significant test.

${ }_{\text {Ns, } * *, * * *}$ Nonsignificant or significant at $P \leq 0.01$ or 0.001 , respectively.

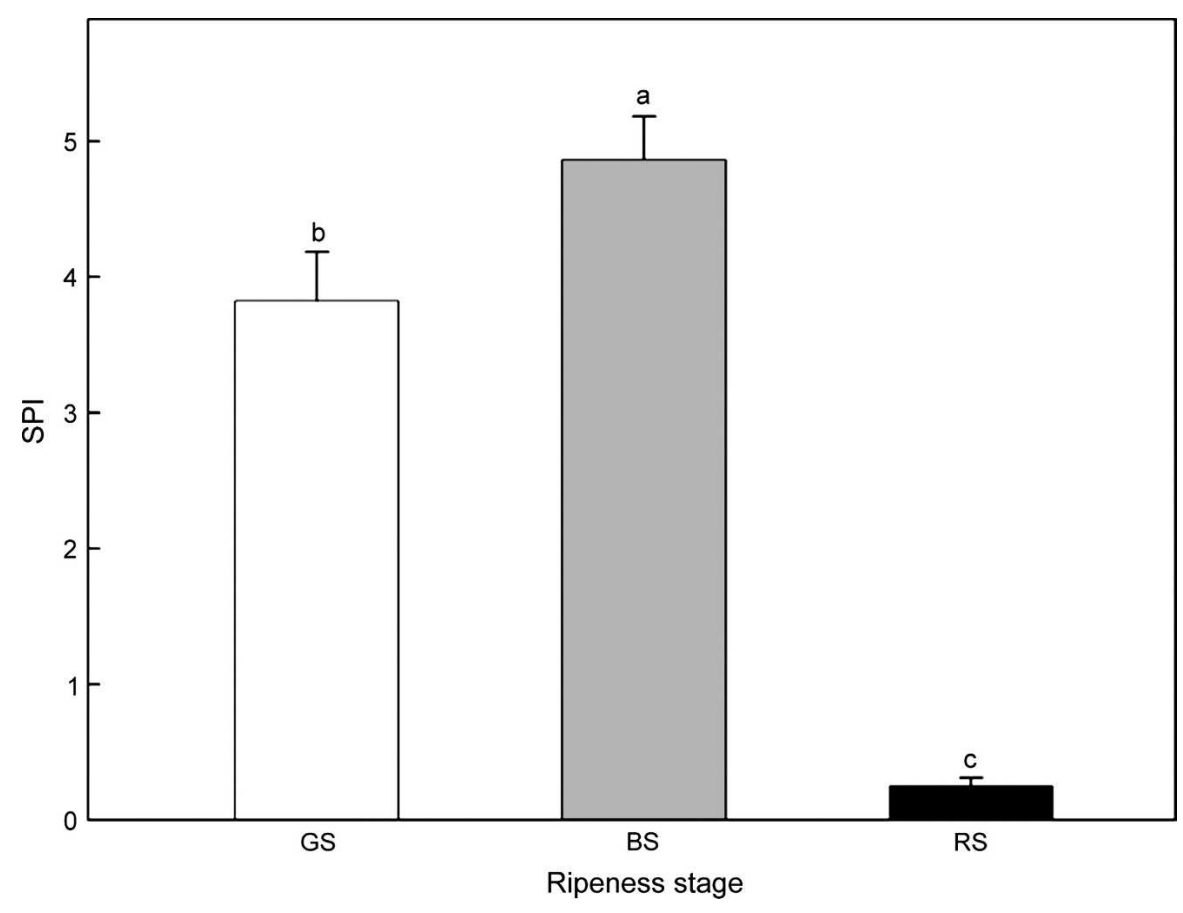

Fig. 5. Effect of ripeness on surface pitting of bell pepper fruit. Fruit that had been stored at $1{ }^{\circ} \mathrm{C}$ for 2 weeks were exposed to room temperature for $2 \mathrm{~d}$ before measurement. Ripeness stages: GS, mature green (full size fruit just before the onset of ripening); BS, breaker (incipient red color formation); RS, red-ripe (fruit completely red in color). Vertical bars indicate SE of the means. The Surface Pitting Index (SPI) is a scale of 0 to 5 , where: 0 , no pitting; $1,5 \% ; 2,6 \%-10 \% ; 3,11 \%-15 \% ; 4,16 \%-20 \%$; and $5,>21 \%$ of the surface area pitted. Means with same letters are not significantly different at $P \leq 0.05$, LSD test.

$10 \% ; 3,11 \%$ to $15 \% ; 4,16 \%$ to $20 \%$; and 5 , greater than $21 \%$ of the surface area pitted. Thirty fruits were used for each replication.

Fifteen fruits were used for scanning electron microscopy (SEM) analysis. Specimens $(3 \times 3 \times 5 \mathrm{~mm})$ were excised from the most severely pitted as well as nonpitted skin regions of fruit. Specimens were fixed immediately with $3 \%$ glutaraldehyde in $0.2 \mathrm{MNa}$-phosphate
$(\mathrm{pH} \mathrm{7.0)}$ for $4 \mathrm{~h}$ at room temperature. The specimens were postfixed for $2 \mathrm{~h}$ in buffered $2 \%$ osmium tetroxide followed by dehydration in an ethanol series. The specimens were dried to a critical point and mounted on copper holders using double-adhesive carbon tape before coating with gold for $3 \mathrm{~min}$. The coated samples were examined under a JEOL JSM-6380LV (Tokyo, Japan) SEM at $15 \mathrm{kV}$.

\section{Results and Discussion}

Storage of bell peppers in sealed polyethylene bags resulted in a modified atmosphere (MA). Similar patterns in the reduction of $\mathrm{O}_{2}$ and the increase in $\mathrm{CO}_{2}$ levels were observed in the package with storage time at all temperatures regardless of fruit ripeness (Fig. 1). With increasing ripeness, the $\mathrm{O}_{2}$ level was higher and $\mathrm{CO}_{2}$ level lower at all storage temperatures. During storage, concentrations of $\mathrm{O}_{2}$ and $\mathrm{CO}_{2}$ changed rapidly in the first $7 \mathrm{~d}$ and subsequently showed small changes over time regardless of storage temperatures.

Water loss is a critical factor in shortening the storage life and increasing deterioration of many fruit during storage (Ben-Yehoshua, 1989; Hardenburg et al., 1986). In the present study, fruit weight (water loss) in a MA was affected by storage temperature and fruit ripeness. During storage, fruit weight decreased gradually with storage time and BS fruit showed slightly higher weight loss than GS and RS fruits (Fig. 2). According to Peleg (1985), fruits and vegetables deteriorate when they lose more than $\approx 3 \%$ to $10 \%$ of their weight causing significant wilting, softening, and shriveling. In the present study, weight loss of fruit after storage was less than $2 \%$, and fruit were firm with no shriveling regardless of ripeness stages or storage temperatures (data not shown). Softening of a few fruits at $1{ }^{\circ} \mathrm{C}$ could be an exception. It is common that fresh horticultural produce exhibit greater weight loss at higher storage temperature because of the increase in vapor pressure at high temperature (MartínezRomero et al., 2003). It was noted in this study that bell pepper fruit in a MA showed more weight loss at lower temperature, although the difference at 1 and $10{ }^{\circ} \mathrm{C}$ was less than $1 \%$ after $28 \mathrm{~d}$ of storage. The increase in weight loss at low temperature 


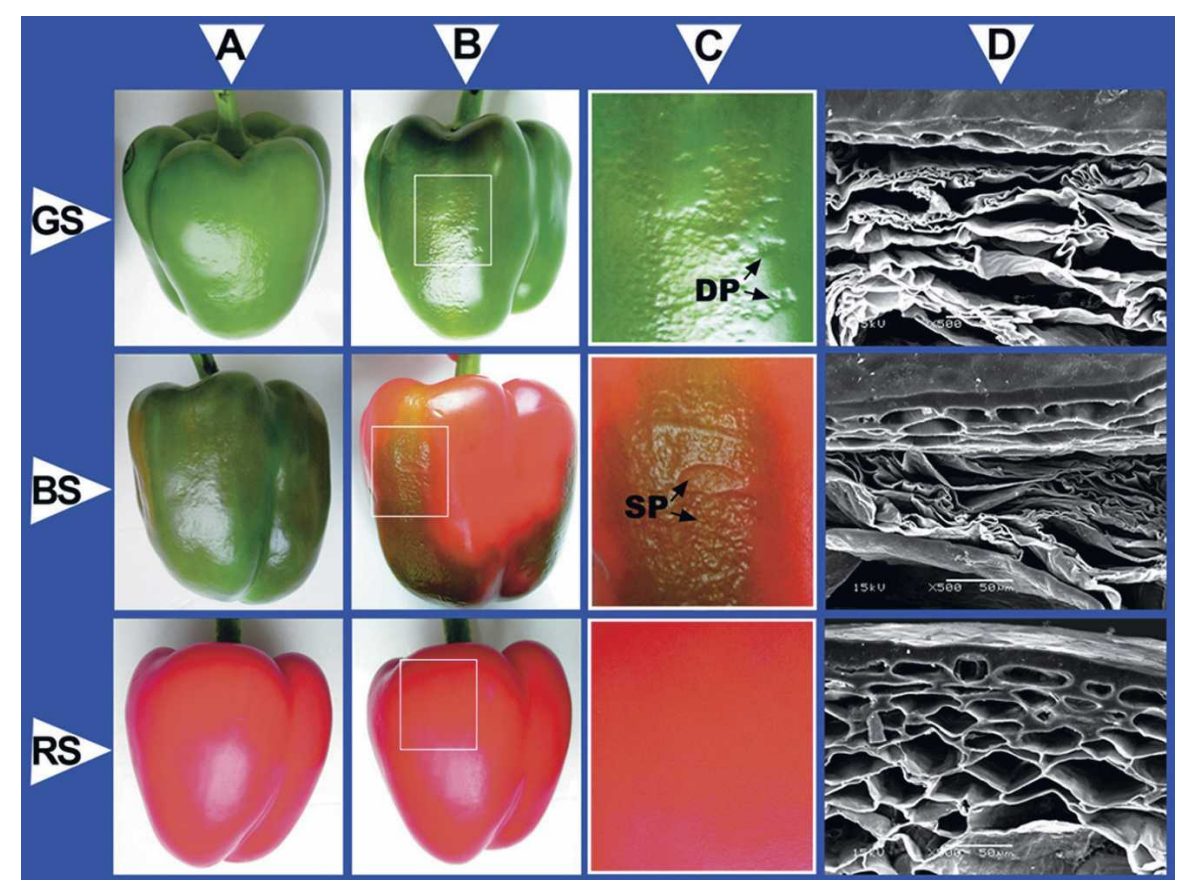

Fig. 6. Effect of ripeness stage on development of chilling-induced pitting on bell pepper skin. Arrows indicate dot-pitting (DP) and sheet-pitting (SP). Fruit that had been stored at $1{ }^{\circ} \mathrm{C}$ for 2 weeks were exposed to room temperature for 2 days before measurement. Ripeness stages: GS, mature green; BS, breaker; RS, red-ripe. (A) Immediately after 2-week storage at $1{ }^{\circ} \mathrm{C}$; (B) After a 2-day exposure to room temperature; (C) The skin area from the square areas shown in (B) at $3.5 \times$ magnification; (D) SEM of a cross section of the skin at $500 \times$ magnification. Bar $=50 \mu \mathrm{m}$.

might be related to development of $\mathrm{CI}$ through cellular breakdown, deterioration of membrane integrity as well as loss of epicuticular wax, which is important in water exchange through cucumber fruit skin (Hakim et al., 1999).

We observed that fruit ripeness, as well as temperature, affected respiration and ethylene production of bell pepper fruit during storage (Fig. 3). At the end of storage, respiration and ethylene production were higher as storage temperature decreased; both were at their highest observed levels in BS fruit held at $1{ }^{\circ} \mathrm{C}$. Respiration and ethylene production of BS fruit increased rapidly during $7 \mathrm{~d}$ of storage at 1 and $5{ }^{\circ} \mathrm{C}$, after which respiration remained constant, whereas ethylene decreased steadily until the end of the storage. This high respiration rate and ethylene production of BS fruits at 1 and $5{ }^{\circ} \mathrm{C}$ is most likely a response to the chilling temperature as has been reported in 'Charentais' muskmelons (Ben-Amor et al., 1999), squash (Lee and Yang, 1999), and cucumber (McCollum et al., 1995). Wang (1987) also reported that an increase in ethylene production is one of the most common responses to chilling and that this increase is most likely the result of increased 1-aminocyclopropane-1-carboxylic acid (ACC) synthase activity at low temperature.

The EL of tissue discs from fruit at all ripeness stages showed an increase with storage time regardless of temperature (Fig. 4). However, a rapid increase in EL was observed in GS and BS fruit after 1-week storage at 1 and $5^{\circ} \mathrm{C}$, and lower temperature caused higher EL regardless of ripeness stages. This increase in EL suggests that GS and BS fruit were more susceptible to chilling temperatures than RS fruit because increased EL is associated with appearance of CI symptoms in many sensitive plant tissues (Saltveit and Morris, 1990). The increase in EL of GS and BS fruit was also associated with higher weight loss of those stage fruit at $1{ }^{\circ} \mathrm{C}$ (Fig. 2), as has been observed in both ripe pepper (Kissinger et al., 2005) and cucumber fruit (Walter et al., 1990).

After storage, skin color changed more in BS than in GS or RS fruit regardless of storage temperature (Table 1). A significant increase in lightness was found in BS fruit at $10{ }^{\circ} \mathrm{C}$, whereas both GS and BS fruit at $1{ }^{\circ} \mathrm{C}$ showed a slight decrease in lightness. At the end of storage, BS fruit at $1{ }^{\circ} \mathrm{C}$ were yellowish-green (higher $\mathrm{h}^{\circ}$ and lower chroma value), whereas those at $10{ }^{\circ} \mathrm{C}$ were vivid reddish-orange (lower $\mathrm{h}^{\circ}$ and higher chroma value). The BS fruit showed a greater change in total color difference than the other two stages of ripeness after $28 \mathrm{~d}$ of storage. Wang (1977) reported that peel color change of fruit during ripening and senescence was highly Gong and Mattheis (2003) and Trebitsh et al. (1993) suggested that breakdown of chlorophyll causes degreening of plant organs during ripening and senescence and that ethylene plays an important role in stimulating chlorophyllase activity.

Chilling-induced pitting significantly reduces bell pepper quality during storage. In several studies conducted on methods to correlated with chlorophyll degradation. reduce $\mathrm{CI}$ in green bell pepper, surface pitting was used to monitor CI (González-Aguilar et al., 2000; Purvis, 2002). In the present study, susceptibility of bell pepper fruit to CI was dependent on their stage of ripeness when placed at a chilling temperature $\left(1^{\circ} \mathrm{C}\right)$. The SPI for BS fruit was 4.8, whereas that for GS fruit was 3.8. The SPI for RS fruit was only 0.2 (Fig. 5). Surface pitting of fruit by chilling typically occurred as dot-pitting (DP), which developed into sheet-pitting (SP) in severe cases. DP and SP appeared simultaneously in GS and BS fruit when chilled at $1{ }^{\circ} \mathrm{C}$ for 2 weeks (Fig. 6). A more severe CI was found in BS fruit, which had higher SP development and deeper peel depression than GS fruit. From our anatomical study, we observed more severe cell collapse with BS fruit after chilling. However, RS fruit had a blemish-free appearance and had no damaged cells on examination by SEM (Fig. 6). Although no CI symptoms were found previously in red-ripe peppers (Lin et al., 1993; Serrano et al., 1997), we did observe trace amounts of pitting in RS fruit at $1{ }^{\circ} \mathrm{C}$ (Fig. 5). Surface pitting occurred only in some RS fruit $(\approx 6$ of 30 fruit; data not shown) after 2 weeks of storage at $1{ }^{\circ} \mathrm{C}$. Future research should determine if surface pitting of RS bell peppers is attributable solely to chilling during low-temperature storage, mechanical damage during postharvest handling, or to preharvest disorders.

Alférez and Burns (2004) concluded that peel disorders are induced by a wide array of biotic and abiotic factors in the field and during postharvest handling and storage. Chlorophyll may play an important role in development of skin pitting. Interestingly, it was noted that the pitted region of the peel in BS fruit remained green (Fig. 6). Peel pitting strongly inhibited color development and chlorophyll degradation in the BS fruit under chilling conditions. We observed that RS fruit did not showed peel pitting after chilling. Grierson (1974) suggested that peel pigments could be involved in resistance of grapefruits to CI. However, Larson (1988) reported that chlorophyll protected plants against oxidative damage. It has also been reported that CI was related to oxidative stress (Harayadi and Punkin, 1991).

A positive relationship between pitting development and water loss was reported by Alférez and Burns (2004), who found that development of peel pitting was triggered by water loss in orange. Ben-Yehoshua (1969) also reported that water potential plays an important role in peel pitting of oranges. Hong and Gross (2000) hypothesized that chilling in tomato causes water to move from the cytosol into the apoplast as a result of cold-induced membrane breakdown and a limited number of sites for binding of cytosolic-free water. Ben-Arie and Sonego (1980) found an increase in pectinesterase activity and a decrease in polygalacturonase activity at chilling temperature. It is possible that a decrease in membrane integrity, an increase in cytosolic water moving out to the intercellular space, and an increase in cell 
wall breakdown by these enzymes could all contribute to increased water loss and thus skin cell collapse in GS and BS fruits under chilling conditions. We could not rule out the possibility that breaker-stage bell peppers are inherently more susceptible to CI so that an experiment with appropriate air control should answer this possibility.

In conclusion, the degree of CI of bell pepper fruit was significantly affected by their stage of ripeness when placed into cold storage at 1 to $10^{\circ} \mathrm{C}$. The most severe pitting was observed in BS fruit after chilling at $1{ }^{\circ} \mathrm{C}$ followed by $2 \mathrm{~d}$ at room temperature. Bell pepper fruits at the BS stage of ripeness showed higher weight loss, respiration, ethylene production, and EL, the change of which was temporally associated with the development of CI.

\section{Literature Cited}

Alférez, F. and J.K. Burns. 2004. Postharvest peel pitting at non-chilling temperature in grape fruit is promoted by changes from low to high relative humidity during storage. Postharv. Biol. Technol. 32:79-87.

Ben-Arie, R. and L. Sonego. 1980. Pectolytic enzyme activity involved in woolly breakdown of stored peaches. Phytochemistry 19:2553-2555.

Ben-Amor, M., B. Flores, A. Latché, M. Bouzayen, J.C. Pech, and F. Romojaro. 1999. Inhibition of ethylene biosynthesis by antisense ACC oxidase RNA prevents chilling injury in 'Charentais' cantaloupe melons. Plant Cell Environ. 22:1579-1586.

Ben-Yehoshua, S. 1969. Gas exchange, transpiration, and the commercial deterioration in storage of orange fruit. J. Amer. Soc. Hort. Sci. 94:524-528.

Ben-Yehoshua, S. 1989. Individual seal-packing of fruit and vegetables in plastic film. In: A.L. Brody (ed.). Controlled/modified atmosphere/ vacuum packaging of foods. Food \& Nutrition Press, Inc., Trumbell, CT.

Francis, F.J. 1980. Color quality evaluation of horticultural crops. HortScience 15:58-59.

Gong, Y. and J.P. Mattheis. 2003. Effect of ethylene and 1-methylcyclopropene on chlorophyll catabolism of broccoli florets. Plant Growth Reg. 40:33-38.

González-Aguilar, G.A., L. Gayosso, R. Cruz, J. Fortiz, R. Báez, and C.Y. Wang. 2000. Polyamines induced by hot water treatments reduce chilling injury and decay in pepper fruit. Postharv. Biol. Technol. 18:19-26.
Grierson, W. 1974. Chilling injury in tropical and subtropical fruits: V. Effect of harvest date, degreening, delayed storage and peel colour on chilling injury of grapefruit. Proc. Trop. Reg. Amer. Soc. Hort. Sci. 18:66-73.

Gross, K.C., A.E. Watada, M.S. Kang, K.S. Kim, and S.W. Lee. 1986. Biochemical changes associated with the ripening of hot pepper fruit. Physiol. Plant. 66:31-36.

Hakim, A., A.C. Purvis, and B.G. Mullinix. 1999. Differences in chilling sensitivity of cucumber varieties depend on storage temperature and the physiological dysfunction evaluated. Postharv. Biol. Technol. 17:97-104.

Harayadi, P. and K.L. Punkin. 1991. Chillinginduced oxidative stress in cucumber fruits. Postharv. Biol. Technol. 1:33-45.

Hardenburg, R.E., A.E. Watada, and C.Y. Wang. 1986. The commercial storage of fruits, vegetables, and florist and nursery stocks. USDA Agr. Hdbk. No. 66:65.

Hong, J.H. and K.C. Gross. 2000. Involvement of ethylene in development of chilling injury in fresh-cut tomato slices during cold storage. J. Amer. Soc. Hort. Sci. 125:736-741.

Kawada, K. 1980. Some physiological and biochemical aspects of chilling injury of grapefruit (Citrus paradise Macf.) with emphasis on growth regulators. University of Florida, Gainesville, FL. PhD Diss.

Kissinger, M., S. Tuvia-Alkalai, Y. Shalom, E. Fallik, Y. Elkind, M. Jenks, and M.S. Goodwin. 2005. Characterization of physiological and biochemical factors associated with postharvest water loss in ripe pepper fruit during storage. J. Amer. Soc. Hort. Sci. 130:735-741.

Lafuente, M.T., M.A. Martínez-Téllez, and L. Zacarías. 1997. Abscisic acid in the response of 'Fortune' mandarin to chilling. Effect of maturity and high temperature conditioning. J. Sci. Food Agr. 73:494-502.

Larson, R.A. 1988. The antioxidants of higher plants. Phytochemistry 27:969-978.

Lee, K.A. and Y.J. Yang. 1999. Effect of chemical treatments on reduction of chilling injury and physiological changes during cold storage of squash (Cucurbita moschata). J. Kor. Soc. Hort. Sci. 40:669-672.

Lin, W.C., J.W. Hall, and M.E. Saltveit. 1993. Ripening stage affects the chilling sensitivity of greenhouse grown peppers. J. Amer. Soc. Hort. Sci. 118:791-795.

Lurie, S. and S. Ben-Yehoshua. 1986. Changes in membrane properties and abscisic acid during senescence of harvested bell pepper fruit. J. Amer. Soc. Hort. Sci. 111:880-885.
Lurie, S., B. Shapiro, and S. Ben-Yehoshua. 1986. Effects of water stress and degree of ripeness on rate of senescence of harvested bell pepper fruit. J. Amer. Soc. Hort. Sci. 116:880-885.

Martínez-Romero, D., M. Serrano, and D. Valero. 2003. Physiological changes in pepino (Solanum muricatum Ait.) fruit stored at chilling and non-chilling temperatures. Postharv. Biol. Technol. 30:177-186.

McCollum, T.G., H. Doostdar, R.T. Mayer, and R. McDonald. 1995. Immersion of cucumber fruit in heated water alters chilling-induced physiological changes. Postharv. Biol. Technol. 6:55-64.

Meir, S., I. Rosenberger, Z. Aharon, S. Grinberg, and E. Fallik. 1995. Improvement of the postharvest keeping quality and color development of bell pepper (cv. 'Maor') by packaging with polyethylene bags at a reduced temperature. Postharv. Biol. Technol. 5:303-309.

Paull, R.E. 1990. Chilling injury of crops of tropical and subtropical origin, p. 17-36. In: C.Y. Wang (ed.). Chilling injury of horticultural crops. CRC Press, Boca Raton, FL.

Peleg, K. 1985. Produce, handling, packaging, and distribution. AVI Pub. Co., Inc., Westport, CT.

Purvis, A.C. 2002. Diphenylamine reduces chilling injury of green bell pepper fruit. Postharv. Biol. Technol. 25:41-48.

Saltveit, M.E. 2002. The rate of ion leakage from chilling-sensitive tissue does not immediately increase upon exposure to chilling temperatures. Postharv. Biol. Technol. 26:295-304.

Saltveit, M.E. and L.L. Morris. 1990. Overview of chilling injury of horticultural crops, p. 3-15. In: C.Y. Wang (ed.). Chilling injury of horticultural crops. CRC Press, Boca Raton, FL.

Serrano, M., M.C. Martínez-Madrid, M.T. Pretel, F. Riquelme, and F. Romojaro. 1997. Modified atmosphere packaging minimizes increases in putrescine and abscisic acid levels caused by chilling injury in pepper fruit. J. Agr. Food Chem. 45:1668-1672.

Trebitsh, T., E.E. Goldschmidt, and J. Riov. 1993. Ethylene induces de novo synthesis of chlorophyllase, a chlorophyll degrading enzyme, in citrus fruit peel. Proc. Natl. Acad. Sci. USA 90:9441-9445.

Walter, W.M., D.G. Epley, and R.F. Mcfeeters. 1990. Effect of water stress on stored pickling cucumbers. J. Agr. Food Chem. 38:2185-2191.

Wang, C.Y. 1977. Effect of amimoethyoxy analogs of rhizobitoxine and sodium benzoate on senescence of broccoli. HortScience 12:54-56.

Wang, C.Y. 1987. Changes of polyamines and ethylene in cucumber seedlings in response to chilling stress. Physiol. Plant. 69:253-257. 